\title{
How Do Romanian Universities Promote Their Educational Offer and What \\ Mechanisms Are Used to Attract \\ International Students?
}

\author{
Cristina Ramona Fit
}

\section{Research Question and Purpose of the Research}

\subsection{Research Question and Aim of the Study}

Strategies at the European level together with the Bologna Process, underline the importance of internationalization. Mobility is of utmost importance on the European agenda and was assumed by the Bologna member countries through the past Ministerial Communiques, by adopting a dedicated strategy for mobility ("Mobility for better learning", Bucharest 2012), by supporting mobility through digital tools (Paris, 2018) or by prioritizing transnational cooperation (Paris, 2018). Romania is still far from reaching the $20 \%$ mobility target by 2020 , but Romanian universities are more and more interested in attracting international degree-seeking students. The reason for this is the decrease in the number of Romanian students over the past years and the aim to increase internationalization (which is mostly perceived as mobility) in the context of a competitive education market. This paper aims to identify how Romanian universities promote their educational offer, if there is a link between their internationalization of higher education strategies and their specific actions. The purpose is to contribute to the improvement of internationalization of Romanian higher education policies by understanding universities' perceptions regarding strategies, actions and mechanisms they use in order to develop mobility and contribute to a better quality of higher education. The paper will present the link between the internationalization strategies of the Romanian universities and the status quo of promoting their educational offer. The article also includes a short analysis on how universities promote their study offer nationally and internationally, taking three Romanian universities as case studies and looking into their institutional internationalization

C. R. Fiţ (凶)

Executive Agency for Higher Education, Research, Development and Innovation Funding,

Bucharest, Romania

e-mail: cristina.fit@gmail.com

(C) The Author(s) 2020

A. Curaj et al. (eds.), European Higher Education Area: Challenges for a New Decade, https://doi.org/10.1007/978-3-030-56316-5_3 
strategies, the strategic plans for institutional development and the instruments used for promoting their educational offer.

The main research questions considered are:

- Is there any correlation between the institutional internationalization strategy, the strategic plan for institutional development and the main activities actually performed to promote their educational offer?

- How do universities promote their educational offer and what mechanism do they use to attract international students?

- Which mechanisms are most efficient in attracting international students?

\subsection{Methodology}

The methodology of the article has a mix of qualitative and quantitative data analysis of documents and data collected through a perception questionnaire. As Byrman (Bryman 1988) stated, each research needs to have a specific research method in order to better answer to the research questions of the study. Therefore, there will be a document analysis of the internationalization strategies and the strategic plans for institutional development, understanding the methods and instruments used for promoting their educational offer.

The universities that were asked to complete the questionnaire will remain anonymous. These institutions were chosen based on the number of students (small or big), their geographical location, in order to cover all areas from Romania, type of institution in terms of public and private, and the institution's mission, comprehensive or technical.

In the end, the article will provide several recommendations on ways to improve the level of promoting the educational offer.

One of the research limitations is the low number of universities that contributed to the questionnaire. However, Romanian universities are rather similar, which is why I considered the institutions that contributed to this study representative at national level.

\subsection{Theoretical and Conceptual Framework}

Jane Knight defined internationalization as "the process of integrating an international, intercultural, or global dimension into the purpose, functions or delivery of postsecondary education" (Knight 2008). Internationalization of higher education, according to Knight, is a process that has two important components"internationalization at home" and "internationalization abroad". De Wit and others (2015) have updated the first definition by Knight on the internationalization of higher education, describing internationalization as being" the intentional process of inte- 
grating an international, intercultural or global dimension into the purpose, functions and delivery of post-secondary education, in order to enhance the quality of education and research for all students and staff, and to make a meaningful contribution to society" (De Wit et al. 2015).

OECD defines internationalization in general terms, according to Pricopie et al., as "the totality of processes whose combined effect, planned or not, is to ensure the international dimension of higher education experience in universities and similar educational institutions" (Pricopie et al. 2009).

Debates from the last several years in the academic communities expanded and lead to a redefining and rethinking of internationalization of higher education. If, at first, the main rationale of internationalization of higher education was perceived as increasing the "international dimension in teaching and research or fostering a climate of greater appreciation for and understanding of other cultures, languages and different ways of approaching and analyzing issues" (Egron-Polak and Hudson 2012), now, according to the 5th Global Survey Report, developed by IAU (Marinoni 2019), the benefits of internationalization are seen as predominantly improving "international cooperation and capacity building" and the "quality of teaching and learning", as the main important benefit. The relevance of internationalization is becoming more and more important, depending on the size of the institution. As stated in the Global Survey Report (Egron-Polak and Hudson 2012), the way institutions approach international dimensions depends very much on the size of the HEI: institutions of small size have the tendency to concentrate more on the mobility dimension (having a strong economic motivation related to the extra funds brought by foreign fee- paying students), while HEIs with a comprehensive character have the tendency to concentrate more on research partnerships.

According to the 5th IAU Global Survey Report, HEIs worldwide increased their interest in internationalization. "However, this increase has happened mainly in HEIs where the level was already high, whereas it has not happened at HEIs where the level was low. This might lead to a growing inequality between HEIs" (Marinoni 2019).

As an EHEA member, Romania has made a series of commitments in the field of education which imply both the internationalization of education and the increase of quality.

During the London Ministerial Conference in 2007, the first strategy that included objectives regarding the development of the internationalization of higher education, "European Higher Education in a Global Setting", was adopted. During the 2012 Bucharest meeting (EHEA 2012), three priorities for 2012-2015 were established: offering quality higher education for everyone, increasing the employability of graduates and enhancing mobility as a way for better learning. At this meeting, internationalization of higher education was recognized as a priority, and the 2020 Strategy for Mobility in EHEA was adopted. Strategies at the European level underline the importance of mobility, such as the newly launched Erasmus+ Program, that has a substantial increase in funding, which translates in better support for universities.

Since mobility has become a priority, especially in the context of a decrease in the number of students in Europe where "populations in many countries are getting older, 
and, in the process, the key 15-to-24-year-old college-aged cohorts are shrinking" (Monitor ICEF 2017) and in the context of a worldwide competition for students (Redden 2019), promoting higher education offers should be among the key topics that dominate the internationalization of higher education agenda in Romania.

\section{Romania-Context and Status Quo}

\subsection{Details About the Internationalization of Higher Education in Romania}

The student population in Romania has been decreasing drastically in the last ten years. If in 2009/2010 the total number of students at public universities was around 624,000 , in ten years the number of students dropped by $26 \%$, reaching 463,000 students in the 2018/2019 academic year. There are many reasons for this, namely population decrease and the decrease in the number of Baccalaureate graduates. Also, there is a major phenomenon of "loss", more specifically "following a generation of children enrolled in the 1st grade in 2003/2004, only $27 \%$ of them reached higher education, and only $20 \%$ finalized the 1 st year of higher education." (UEFISCDI P. P., Access in higher education policy brief 2018). Some of the reasons for this loss are repetition, dropout, and migration (Table 1).

In terms of the evolution of students at public universities (Bachelor, Master, $\mathrm{PhD})$, please see below a set of data from CNFIS and ANS:

Table 1 Evolution of Student Population in the last ten years for public HEIs

\begin{tabular}{l|l|l|l|l|l|l|l|l|l|l}
\hline & $\begin{array}{l}2009 / \\
2010\end{array}$ & $\begin{array}{l}2010 / \\
2011\end{array}$ & $\begin{array}{l}2011 / \\
2012\end{array}$ & $\begin{array}{l}2012 / \\
2013\end{array}$ & $\begin{array}{l}2013 / \\
2014\end{array}$ & $\begin{array}{l}2014 / \\
2015\end{array}$ & $\begin{array}{l}2015 / \\
2016\end{array}$ & $\begin{array}{l}2016 / \\
2017\end{array}$ & $\begin{array}{l}2017 / \\
2018\end{array}$ & $\begin{array}{l}2018 / \\
2019\end{array}$ \\
\hline $\begin{array}{l}\text { Total } \\
\text { no of } \\
\text { students }\end{array}$ & 624,654 & 616,506 & 576,290 & 520,853 & 479,876 & 461,582 & 448,939 & 426,567 & 473,304 & 463,135 \\
\hline
\end{tabular}

Source (2009-2015) CNFIS, available data according to public HEIs reports — data ref January Source (2016-2018) ANS

Since the paper analyzes the correlation between the institutional internationalization strategies and the main activities actually performed to attract international students, it is relevant to write a short introduction on the number of international students, countries of origin and evolution in the last ten years. Romania had its record on international students in the early ' 80 s, when $10 \%$ of students were international. As a result of political changes, the number of international students began to decrease (Deca and Fit 2015). In the last years (UEFISCDI P. P., Internationalization of Higher Education Policy Brief 2017), analyzing data from 2017, the most popular academic programs with foreign students are taught in French. Most of the international students study a bachelor's degree, and more than one third of the nonEU students in Romania study mostly Medicine, Dental Medicine and Pharmacy. 
Most of these fields are accessed by students from Israel, Moldova, Tunisia, Syria, Morocco, Lebanon, Albania, Jordan and Iran.

In terms of the evolution of incoming international degree students, in the last ten years in Romania there was a 74\% increase from 15,538 international students in 2009/2010 (together with Romanian ethnics) to 27,048 in 2018/2019. The last available clear data is from 2018. If in 2015/2016, the percentage of international degree students out of the total student population (considering the INS data, meaning public and private universities) was 5.5\% (MENCS 2016, pp11), in 2018/2019 the percentage is $5.8 \%$.

Top incoming countries for international degree students in 2018/2019 are Republic of Moldova, Israel, France, Italy, Germany, Tunisia, Morocco, Greece, Serbia and Hungary.

In terms of incoming credit mobility students, in 2009/2010 there were 1,359 incoming credit mobility students while in 2018/2019 the number of incoming students increased by $194 \%$ to 3,995 number of students.

As for outgoing credit mobility students, in 2009/2010 there were 4,768 students, and in 2018/2019 there are 7,812 students outgoing.

\section{National Policies}

Romania does not have any national internationalization strategy formally acknowledged by the Ministry of Education and with a dedicated budget. There is still the internationalization strategy developed during the IEMU ${ }^{1}$ project in 2015 which does not have any action plan and it was not politically approved.

An in-depth analysis of public strategic documents of Romanian HEIs from 2013, made during the IEMU project (2014), reveals that 43 of 92 universities had vague or missing information on internationalization and mobility in their institutional strategies and operational plans. 30 universities mentioned internationalization of education, mobility and partnerships in general terms, but HEIs had no comprehensive strategy with concrete targets on this dimension. Thus, only 19 universities have set detailed objectives and concrete references regarding the internationalization of HE (at the date of the study 2014) (Deca et al. 2016).

As for internationalization governance, Romania has no institution dedicated to managing the internationalization of higher education. The Ministry of Education is the official institution that manages internationalization currently but with no dedicated national strategy or objectives. In terms of attracting international students, Romania has no marketing strategy, policies or projects.

Between 2016 and 2017, The National Council of Rectors (NCR) started in a more informal way to manage one of the aspects of internationalization, namely promotional activities. Unfortunately, by the end of 2019, there are no clear objectives, a strategic approach or joint requests to the Ministry of Education for support in the

\footnotetext{
${ }^{1}$ Internationalization, equity and institutional management for a quality higher education' (IEMU) project, managed by UEFISCDI during 2013-2015, and financed by the Sectorial Operational Program Human Resources Development (SOP HRD), seek to promote the development of a national strategy by September 2015 .
} 
development of internationalization. Managing promotional activities (participation at educational fairs and conferences) by NCR has so far proven to be successful, as developing a bottom-up process of involvement rather than a top-down is a positive aspect, but there are, unfortunately, some negative aspects of this approach as well. Not all universities are actively involved in the process of promotion or developing internationalization at national level, there is no common budget dedicated to internationalization activities, as well, every HEI has an individual and different budget for promotional activities.

Following the recommendations from the Strategic framework for internationalization of Higher Education in Romania, a document developed during the IEMU project, The Ministry of Education started the $\mathrm{FDI}^{2}$ program to incentive HEIs that want to enhance their internationalization activities.

As for budgets for internationalization activities, HEIs started to have internal budgets dedicated mostly to promotional activities, more specifically for participation at educational fairs or conferences.

Nationally, as a result of the IEMU project, www.studyinromania.gov.ro was launched in 2015, a website dedicated to promoting the Romanian higher education and attracting international students. If in 2015 there were 12 HEIs which submitted their educational offer with 740 study programs, in 2019 there were 45 universities that submitted at least one study program, which is a total of 3,677 study programs in 15 languages, most of them taught in Romanian or in Romanian and another language, as well as in English, French, German or Hungarian.

Presently, according to the HG no. 326/2019, there are 235 programs in English, 95 programs in French, and 88 programs in German offered by Romanian universities.

An analysis of the main findings in 20 HEIs self-studies, SWOT analysis and summaries of the universities' goals for internationalization together with the observations of the expert teams reveals that around half of all universities which participated in the IEMU project reported that they had no marketing or communication strategies (UEFISCDI 2015). The conclusion is that most universities had very limited capacity and resources to design and implement such strategies. This gap can be perceived as an obstacle to attracting international students and scholars. The absence of a communication strategy was visible in HEIs websites, which often provided insufficient information, were lacking information in English, or there was no strategy to recruit international students.

After analyzing 19 of the HEIs that developed an internationalization strategy during the IEMU project, all these HEIs have the same strategy they developed in $2014 / 2015$, but some of the institutions made a few updates. The same recent analysis revealed that 13 out of 19 universities mentioned in their internationalization strategy that they want to raise the visibility of their educational offer or to develop a marketing strategy. Out of these 19 HEIs involved in the IEMU, 17 have a website in English with information for international students, and 18 of them have a dedicated page for international students with at least basic information, such as admission process and educational offer. At the same time, a recent analysis of the 47 public HEIs in

${ }^{2}$ FDI-The Institutional Development Fund, given by the Ministry of Education. 
Romania, reveals that 37 HEIs have a website in English that is at least $80 \%$ translated and includes information for international students.

In the context of a more competitive higher education area in terms of attracting students, with a focus on international students, new trends have developed in the education sector, "what some have called global marketization". "The term "marketization" refers to the fact that as the HE market has become progressively more competitive, many HE institutions (HEI) have started to engage in strategic marketing and design marketing activities with the aim of increasing the number of applicants to their universities (Fernando Angulo-Ruiz 2016)". In terms of mechanisms to promote their educational offer or to communicate with enrolled and prospective students, 46 out of the 47 public HEIs analyzed have a Facebook page on which universities communicate, but not always in English or a foreign language. In terms of an Instagram account, 35 HEIs out of 47 have an account, but this does not necessarily mean that they have an active account (*active account means sharing at least once a week).

Following a questionnaire developed by the Ministry of Education in 2016 that was meant to help the Ministry better understand HEIs priorities on internationalization, out of 92 HEIs, 52 universities submitted their answers, 43 public HEIs, 9 private institutions and 5 having a military profile. The questionnaire findings revealed 5 top internationalization priorities, namely increasing partnerships with international universities, increasing students and academic staff mobility, promoting the university at an international level (including increasing the visibility of the educational offer or actions related to university branding and marketing), attracting international degree students, internationalization of the curricula and priorities regarding research (partnerships development or involvement in research networks).

In terms of attracting international students, the priority areas were the following: EU member states, EU (Non-member states), DCI Asia, South-Mediterranean (ENI SOUTH), Eastern Partnership (ENI EAST).

\section{Case Study -Analysis of Romanian Higher Education Institutions}

\subsection{Details About the Case Study Universities}

\section{Types of Universities}

To understand if there is a link between the internationalization strategies and institutional development plan of HEIs in Romania, I have chosen three case study universities (which will remain anonymous) for which I have analysed their strategies and looked for similarities between objectives and targets. To these three case study institutions, I have also applied a questionnaire. These HEIs were chosen based on the number of students (small or big), their geographical position (covering most areas in Romania), the type of institution (public or private), and the institution's mission, 
comprehensive or technical. The main reason for considering all these indicators while choosing the case study universities was to best cover the types of higher education institutions that exist in Romania. To continue, in order to keep the anonymity of the HEIs that completed the questionnaire, they will be defined as:

- University 1 (U1), big public university, in the technical field, situated in NorthEast Romania

- University 2 (U2), big public university, with a comprehensive mission, situated in the West part of Romania and

- University 3 (U3), small private university, comprehensive mission, situated in South Romania.

All case study universities have developed their most recent internationalization of education strategy during 2014/2015 in the IEMU project. Most of the HEIs made an update of the previous strategies but in a few areas.

\subsubsection{Analysis of the Internationalization Strategies}

Even though there is a variety between the analyzed strategies, the goals for internationalization covered the following areas (first four areas are priority areas as stated by the universities):

Mobility-All case study universities want to enhance incoming and outgoing mobility of students, academic or administrative staff. Main goals refer to increasing numbers, but the private university mentioned increasing mobility opportunities for academic staff and highlighting the qualitative aspect of mobility, such as its impact on institutional development. It is worth mentioning that all case study universities set at least one measurable target referred to increasing mobility for students or academic staff.

Internationalization at Home - The most common goals focused on the internationalization of the curriculum, increasing the number of programs taught in foreign languages, especially English, increasing language skills (mostly English) of the academic, auxiliary and administrative staff; creating an international and friendly environment through extracurricular activities and attracting international speakers/teachers. One university also mentioned focus on developing double degree programs. Moreover, universities mentioned creating a buddy system dedicated to international students. None of the universities proposed to introduce international competences (such as intercultural competences, language skills for both teachers and students, "skills, values and behaviours that prepare young people to thrive in a more diverse and interconnected world" Savvy 2019) into the curriculum (Jones 2013; Leask 2009), showing that the concept of Internationalization at Home is not well understood.

Marketing and promotion-All institutions formulated goals related to marketing and promotion. The main common goal was to increase the international visibility of the university and to design a dedicated marketing strategy or have defined mar- 
keting elements. The private university stated as an objective to become involved in new international associations or networks.

Partnerships-The private comprehensive university and the public technical institution mentioned goals to develop a network of relevant partners, increase the percentage of non-EU partners, increasing bilateral partnerships or focus more on developing strategic partnerships with international networks. Worth mentioning is the fact that institutions did not seem to pay attention to strategically choosing and prioritizing partnerships, resulting in a focus on the quantity rather than the quality of the partnerships. Focusing on quantity could, in many cases, lead to inactive partnerships.

Research-All HEIs expressed interest in this area, especially in developing more international research partnerships, creating a framework for academic scientific research in order to build a competitive academic and research environment, thus attracting new funding opportunities and international researchers. The private comprehensive university mentioned developing interdisciplinary research programs focusing on international relevant topics and finding a more strategic way of choosing partnerships.

Services for international students-The public technical institution and the private comprehensive one have objectives to improve services for international students, but none addressed services for international staff.

Internal organization matters-The public technical and the private comprehensive institutions proposed goals that address internal organizational issues, mainly focusing on digitization of various processes, such as recruiting, admission process and adapting to modern communication instruments.

Quality of educational provision-Two HEIs, both public universities, want to improve the level of internationalization of the curriculum, meaning to adapt to scientific and technological evolution and as well to have high-quality programs, this being a pre-condition to increase institutional branding and to attract international students.

\subsubsection{Priority Areas for Internationalization}

In the questionnaire developed for this study, one of the questions referred to priority areas for which institutions set targets and objectives and all institutions have chosen four main areas, out of nine, which are: mobility, internationalization at home, marketing and promotion, and partnerships. As data shows, from the internationalization strategy analysis, even though 3 out of 3 HEIs mentioned increasing their education offer visibility or developing a marketing strategy, in the end, the public technical institution has an actual marketing strategy in place. 


\subsubsection{Internationalization Strategy Versus HEIs Strategic Plan Analysis}

While analyzing the internationalization strategies and the Institutional Development Strategy for each institution, the current study developed the following matrix. First, the study looks if there are any common dimensions between those two documents and then attempts to identify the same key words in the strategies searching for similarities (Fig. 1).

Please see below the matrix and results.

As a general conclusion, all institutions had comprehensive institutional documents. As J. Knight and de Wit say "comprehensive internationalization does not reflect widespread reality, however: for most institutions around the world, internationalization is still characterized by a collection of fragmented and unrelated activities" (Knigh and de Wit 2018). Looking at the internationalization dimensions that were defined in the internationalization strategies versus main areas defined in the institutional strategies, one can conclude that there is a certain link between those two strategic documents developed by the case study institutions, but it is not clear if there is a real connection between the strategic approach and the actions. Analyzing from the perspective of institutional strategy, for each dimension defined in the document, we could find a common denominator in the internationalization strategy. The main six areas that were common for all three universities are: Internationalization, Branding and International Communication, Partnership with Students and Student Services, University Management and Quality Assurance and the last dimension was Entrepreneurship and Bridge with Economic Stakeholders. It is important to keep in mind that "the presence of a strategy does not necessarily align with a strategic approach to internationalization if there are no activities to implement it and support structures in place, if the strategy is not monitored, and if progress is not evaluated" (Marinoni and de Wit 2019).

Internationalization - as it can be seen in the "Strategy Matrix", in the institutional strategy there were specific goals related to quality of education provision (e.g. goals for increasing the internationalization of the curriculum), goals related

\begin{tabular}{|c|c|c|c|c|c|c|c|c|}
\hline $\begin{array}{l}\text { Quality of } \\
\text { educational } \\
\text { provision }\end{array}$ & Research & Mobility & $\begin{array}{c}\text { Services for } \\
\text { international } \\
\text { students }\end{array}$ & $\begin{array}{c}\text { Internal } \\
\text { organization } \\
\text { matters }\end{array}$ & $\begin{array}{c}\text { Internationalization } \\
\text { at home }\end{array}$ & Marketing & Partnerships & \\
\hline \multirow[t]{4}{*}{3} & 3 & 3 & & & 3 & 3 & 3 & Internationalization \\
\hline & & 3 & & & & 3 & & $\begin{array}{l}\text { Branding and international } \\
\text { communication/mkt }\end{array}$ \\
\hline & & & 3 & & & & & $\begin{array}{l}\text { Partnership with students } \\
\text { and Student servicees }\end{array}$ \\
\hline & 3. & & & & & & & Research and Innovation \\
\hline \multirow[t]{2}{*}{3} & & & & 3 & 3 & & & $\begin{array}{c}\text { University management and } \\
\text { Quality Assurance }\end{array}$ \\
\hline & & & & & & & 3 & $\begin{array}{l}\text { Entrepreneurship \& bridge } \\
\text { with economic } \\
\text { stakeholders/market place }\end{array}$ \\
\hline
\end{tabular}

Fig. 1 Strategy Matrix-Links between Institutional internationalization strategies and HEIs Institutional Strategies 
to research (e.g. developing strategic partnerships to increase research and innovation), goals for mobility (most of them related to increasing both incoming and outgoing mobility for all stakeholders), internationalization at home (e.g. more visiting/international professors or international conferences), marketing (goals related to increasing universities' visibility at international level, developing marketing strategies to attract more students and international students), partnerships (increasing strategic partnerships with priority countries or networks).

Branding and International Communication-Universities had objectives related to mobility (such as international marketing in order to promote the HEI internationally or boosting university's scientific performances and increasing the national and international visibility of the research results) and marketing (setting specific goals related to marketing indicators and promotion).

Partnership with Students and Student Services-Institutions developed objectives related to student services, both national and international. The public comprehensive university stated the aim to create a study package for international students (that should incentive prospective international students and include teaching materials, information materials, accommodation, scholarships). Similarly, the private comprehensive university mentioned "Increasing students motivations through the use of a diversified study scholarship system". The same private university mentioned objectives in terms of streamlining the communication process with students through secretariats or the virtual environment.

Research and Innovation-All institutions had objectives related to research, such as developing new international research partnerships, increasing collaboration with international researchers, or receiving national or international accreditation for the research centres created at institutional level.

University Management and Quality Assurance-All institutions had objectives related to the quality of education provision (aims to increase the quality of the programs and adapt to international standards), internal organization matters and matters regarding internationalization at home.

Entrepreneurship and Making Connections with Economic StakeholdersThis dimension was not present in the internationalization strategies, but it was important to state its presence since all universities had different objectives related to ways to better connect higher education with the labour market.

To conclude, there is a link between the internationalization strategies and the strategic plans for institutional development, since there are similarities between focus areas and objectives. On paper, everything seems to connect well, but the question remains if the institutional strategies and the implemented actions correlate. This will be discussed, later in the paper.

\subsection{Questionnaire Analysis-Collecting HEIs Answers}

To better understand if there are correlations between the institutional strategies, the internationalization strategies and the actions implemented by institutions, I have 
developed a questionnaire. The role of the questionnaire was to see the main activities performed by HEIs to promote their educational offer. Moreover, the questionnaire reveals what mechanisms institutions use to promote their institution and attract international students and which of these are perceived as most efficient in completing their objective to attract international students. The following questionnaire designed especially for this study contains 25 questions. Some of the questions were related to a better understanding of the main internationalization priority dimensions, priority areas of interest in terms of attracting international students, information about marketing objectives, such as goals to attract international students, or budget allocated for promotion. Other questions were related to indicators that institutions collect for a better understanding of the evolution of their actions and efficiency, in terms of mechanisms HEIs use to attract students. There were also questions related to perception, namely if and how HEIs perceive the impact of internationalization on the quality of education.

The role of the questionnaire was to conclude my first research question (if there are any correlations between the institutional strategies and the main activities performed to promote their educational offer) and respond to my last two research questions.

First, I will analyze HEIs perception regarding the link between strategies and actions, as well as the impact of internationalization on the quality of higher education. I will then move forward to analyze what mechanisms institutions use to attract international degree-seeking students.

\subsection{HEIs Perceptions: Link Between Strategy Versus Actions and the Impact Internationalization Has on the Quality of Higher Education}

Two universities (U1 public, technical and U3 private, comprehensive) consider that there is a very high correlation (80-100\%) between the internationalization strategy and the actions they implement. The public comprehensive institution (U2) stated that there is a relative correlation (around $20 \%$ to $40 \%$ ) between the implemented activities and the objectives from the internationalization strategy.

In terms of HEIs perception regarding the impact of internationalization of higher education on the quality of education in the university, public universities consider that actions related to internationalization of higher education have a very high or high impact on the quality of education within the university. The private institution perceives actions related to internationalization with relative impact (20-40\%) on the quality of education in the institution.

Despite the last response, the private university (U3) considers that the existence of an internationalized curricula has a very high impact on the quality of the program, while the public universities perceive that the existence of an internationalized curricula has a high impact (U1) and a relative impact on the quality of the program. 
Public universities perceive the curricula of their study programs, internationalized in a relative way, while on the other hand, the private university finds the curricula of their study programs internationalized at a very high level.

\subsection{Priority Countries to Attract International Students}

According to a self-study report completed by all case study universities, in 2014, most of the HEIs did not have priority countries or regions. At that time, most institutions did not have the concept of "prioritizing countries". Most international degree-seeking students in 2014 were from the Eastern Partnership (ENI EAST) from The Republic of Moldova, Europe (Member states) and South-Mediterranean (ENI SOUTH) - mostly Israel, Morocco. There were also some students from Turkey (Europe-non-member states).

In 2017/2018, according to CNFIS data, the top three regions for international degree-seeking students were the Eastern Partnership (ENI EAST) - most of the students were from Republic of Moldova, Romanian ethnics, South-Mediterranean (ENI SOUTH) - Israel, Tunisia, Morocco or Palestine and Western Balkans IPASerbia, Albania. We can see that the focus changed from European countries (member states) to South-Mediterranean (ENI SOUTH) or Western Balkans IPA.

In 2019, when universities were asked to complete their priority areas for attracting international degree students, there were three main areas that were chosen by the public universities as the main priority:

1. South-Mediterranean (ENI South), this includes the following countries: Algeria, Egypt, Israel, Jordan, Lebanon, Libya, Morocco, Palestine, Syria, Tunisia

2. DCI Asia, this includes Afghanistan, Bangladesh, Bhutan, Cambodia, China, DPR Korea, India, Indonesia, Laos, Malaysia, Maldives, Mongolia, Myanmar, Nepal, Pakistan, Philippines, Sri Lanka, Thailand and Vietnam and

3. Region 9 with Iran, Iraq, Yemen

There is a shift between past priority areas and present ones, and a shift from a nonpriority type of recruitment to a more aware and prioritized one. South-Mediterranean (ENI South) remained a priority, but two other new areas were added: DCI Asia and Region 9. HEIs are following international trends that highlight, according to the Institute of International Education, the top 10 countries (Institute of International Education 2019) of origin of the degree-seeking students in the USA are mostly from DCI Asia. An interesting difference between the universities was the fact that the private university mentioned one area as a priority for incoming degree-seeking students, DCI Central Asia, while the public universities mentioned four and five regions as priority areas, out of which three regions were stated the same for the public institutions.

In order to find if there is any correlation between objectives (in this case the stated priority countries) and the actions (in this case the participation at International Education Fairs), I have asked which are the international fairs universities took part in 
over the past four years. The analysis indicates a weak correlation between objectives and implemented actions. If we compare the responses by labelling institutions as comprehensive and technical, we note that both comprehensive institutions participated in 14 educational fairs over the last four years, with two to four participations in targeted countries, according to their stated priorities. The technical university participated in 10 fairs, with only two in line with the objectives. All other participations in international fairs could be perceived as actions that were aimed at attracting international credit mobility students.

The small number of participations at targeted promotional events indicates a partial correlation (10-30\%) with HEIs' strategic objectives. It is worth mentioning that starting with 2018, all universities increased their participation at international education fairs, including the EAIE Conference (both 2018 and 2019), which constitutes both a learning experience for the university representatives (in terms of internationalization) and a good opportunity for networking and establishing new partnerships.

\subsection{Marketing Strategy and Promotion}

The comprehensive institutions stated that they do not have a marketing strategy per se, but they have defined objectives and actions. The technical institution (U1) confirmed that they had developed a marketing strategy. In terms of promotion budget to attract international students, all institutions, no matter their category, said they have an allocated budget of more than 10,000 Euro per year. A hypothesis is that most of the allocated budget is used for international education fairs.

\subsection{Indicators Considered by Institutions When Analyzing the Impact of the Internationalization Strategy (Promotion) to Attract International Students}

The International Relations Department monitors the internationalization strategy and/or marketing plan, according to all institutions. The four indicators that all universities consider when monitoring the impact of their actions with regards to attracting international students are the number of international degree students, the number of incoming credit mobility students, the number of participations at International Education Fairs and the number of active partnerships with international universities. U1, a public technical university that has a marketing strategy and U3, a private comprehensive university, stated that they analyze the increase or decrease of active partnerships with international universities, due to International Education Fairs participation; on the other hand, the comprehensive HEIs look at the number of international students applying for degree mobility (U2, public university and 
the U3, private institution). The technical public university (U1) and the comprehensive private institution (U3) consider both, eight indicators (not the same) out of 16 indicators presented in the questionnaire when analyzing the impact of the internationalization strategy.

\title{
3.7 Mechanisms HEIs Use to Promote Their Educational Offer
}

Promoting the educational offer is not easy considering the large number of competitors worldwide, the budget or the strategy that top countries/ institutions have.

All case study institutions stated that the used mechanisms to attract international degree-seeking students are their English website, HEI presentation video in various languages circulation, participation at International Education Fairs, promotion via the national portal www.studyinromania.gov.ro, promotion via other platforms and through word of mouth (through teachers, students or existing partnerships). The other platforms public HEIs use to promote their education offer are keystoneacademic.com, studyportals.com, masterstudies.com and educations.com.

Two universities (U1, public, technical HEI and U3, private, comprehensive HEI) stated they use specialized companies for promoting and recruiting international students. In terms of promotion via their Facebook page, both comprehensive institutions, U3 private HEI and U2 public HEI stated they use this mechanism. The private university stated that they are currently using e-mailing campaigns.

By comparison, the private university uses 10 mechanisms out of the 16 presented in the questionnaire to promote their educational offer, while the public institutions use 8 mechanisms. Promotion through Facebook paid campaigns, via Instagram, through Instagram paid campaigns, via HEI YouTube Channel or other conferences to attract international students are not mechanisms of interest to universities.

\subsection{Perceived Most Important Mechanisms and Most Efficient in Attracting International Degree-Seeking Students}

\begin{abstract}
All universities perceive "highly important" and "important" mechanisms to attract international degree students the following: English website, word of mouth (through teachers, students or existing partnerships), participation at International Education Fairs, promotion via other platforms/portals, HEI presentation video in various languages, promotion via studyinRomania.gov.ro portal. The other mechanisms are considered relatively important, less important or not important at all. Those that are stated as less and not important at all are promotion via HEI YouTube Channel, conferences to promote and attract international students, promotion through Facebook paid campaigns, promotion via Instagram page and promotion through Instagram paid campaigns (Fig. 2).
\end{abstract}




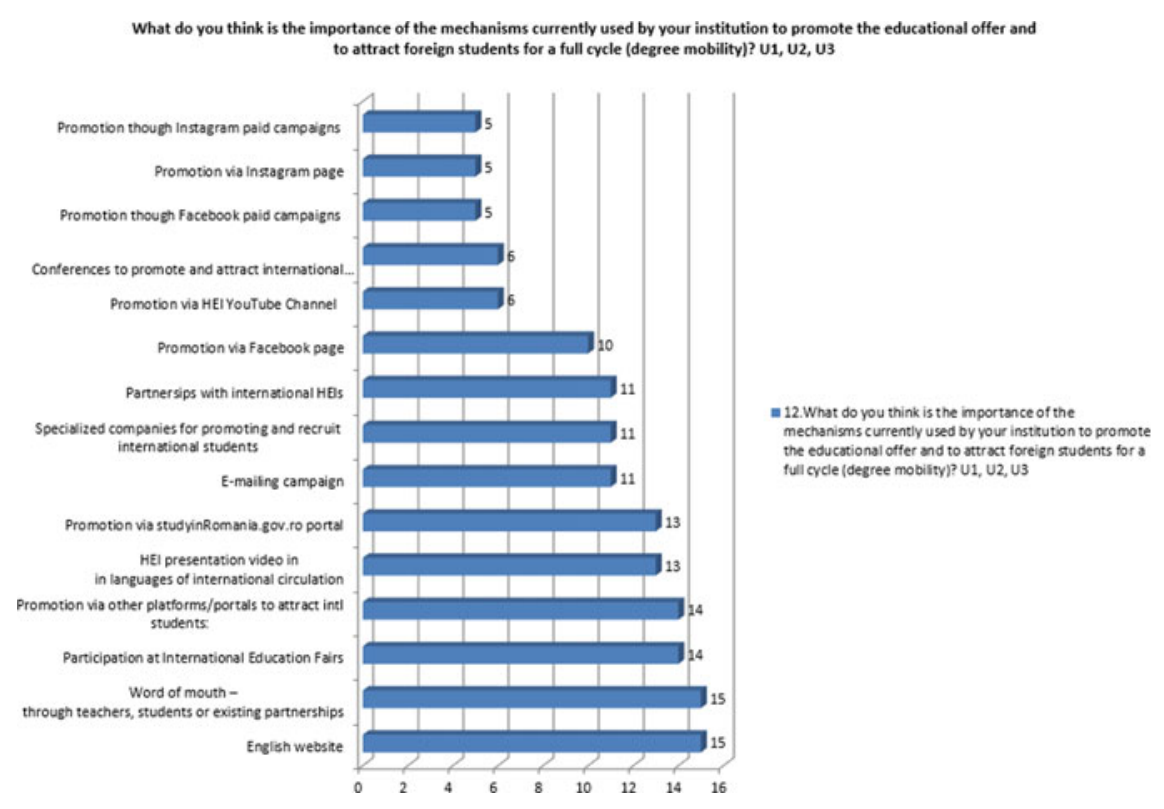

Fig. 2 Most important mechanism currently used to attract international degree-seeking students

When asked about the most efficient mechanisms to attract international degree students, universities stated as highly efficient or efficient the same five mechanisms mentioned above as most important, skipping the promotion via study in Romania.gov.ro portal, and instead adding partnerships with international HEIs.

\subsection{Correlation of Targets for International Degree-Seeking Students From the Internationalization Strategy}

From the case study universities only, the comprehensive ones stated an actual target for attracting international students. In their internationalization strategies, both comprehensive universities aim for an increased number of international students, with $25 \%$ for the public institution and $20 \%$ for the private one.

Data shows that the number of international degree students increased by $10 \%$ for the public institution and $17 \%$ for the private one, compared with 2015/2016, the year when universities started implementing their new internationalization strategies. All three universities increased the overall number of international students but did not meet the target. 


\section{Conclusions}

When looking at the correlation between the institutional internationalization strategy, the strategic plan for institutional development and the main activities performed to promote their educational offer, the analysis shows that there is a relative correlation. As stated before, there are various correlations between objectives from both institutional documents (for each case study), but there is also a rift between objectives and actual actions.

Even though the institutions stated they want a marketing strategy to increase the university's visibility internationally, only one higher education institution has managed to develop such a document. Nevertheless, despite the lack of a marketing strategy, institutions had several actions that were meant to increase the HEI's visibility or to attract more international students.

In terms of prioritizing countries, the private university seems to be more focused, choosing one priority area for attracting international degree-seeking students. This type of prioritization could be more efficient in terms of managing the available internationalization budget and have proven results. But, as we could see from the analysis, if we look at the surveyed institutions, participation at international educational fairs is only partially correlated (around 10-30\%) with stated priority countries. From this point of view, we can conclude that institutions fail to correlate their actions with the stated objectives. At the same time, when we look at the perception between internationalization strategies versus actions, most universities perceive there is a high correlation (80-100\%) between the internationalization strategy and the actions they implement.

\section{How do universities promote their educational offer and what mechanisms do they use to attract international students?}

Even though the surveyed universities have internationalization strategies, most of them lack a marketing strategy (as a standalone document or as a part of the overall internationalization strategy) to attract international students or to promote their educational offer. This shows that institutions do not have clear marketing objectives, targets, priorities and well-defined mechanisms that could help build their brand. Institutions promote themselves through the English website, presentation video, participation at International Education Fairs, promotion via the national portal www. studyinromania.gov.ro, promotion via other platforms and word of mouth (through teachers, students or existing partnerships). Even though these mechanisms are used, universities do not monitor relevant indicators in order to see the actual efficiency or to have a better understanding of where and why they should use a specific mechanism. Institutions use these mechanisms to attract international students in an ad-hoc way and are not in line with trends in international education marketing or with the new generation, the so-called the Generation $\mathrm{C}$ (the connected generation).

Even though studies (Research Center Pew 2018) show that the new generation is mostly active on social media, the most frequently used social media platforms for the 18-24 age group being YouTube, Facebook and Instagram, institutions do not 
yet perceive social media as an essential mechanism to advertise their educational offer or to attract international students.

Most of the surveyed universities use specialized companies for promoting activities and recruiting international students. Using professionalized help can be a good option when institutions do not have specialized resources to attract international students or since specialized companies have direct contact with the prospective students.

When analyzing the impact of the internationalization strategy, universities fail to consider indicators that could show them relevant data and could give their actions a more focused approach on the objectives, such as the HEI website traffic (international users). This could help institutions understand from which countries originate most of their prospective students, which can then lead to prioritizing all or most educational marketing and promotion actions in certain or dedicated countries. It could be a great opportunity to analyze which webpages from the university website are most accessed to introduce more relevant information.

Private or public, technical or comprehensive, universities seem to use 8-10 mechanisms to promote their educational offer. In a context where universities understand and know very well their target audience, there would be no need to have many mechanisms to promote their educational offer. Less, but more targeted mechanisms can certainly lead to more results. However, there is no certainty that universities are aware of their target audience with its specifics and their main selling points.

\section{Which mechanisms are most efficient in attracting international students?}

Most efficient mechanisms to attract international degree students stated by universities were the English website, word of mouth, participation at International Education Fairs, promotion via other portals, HEI presentation video and partnerships with international HEIs. It is interesting how institutions perceive some mechanism highly efficient or efficient without having an actual indicator that can clearly measure or show data in this sense. The English version of their website is seen very effective, but when measuring the impact of the strategy or mechanisms used, none of the HEIs monitor HEI website traffic (international users).

The same happens with word of mouth, because it is a very powerful mechanism, although it also lacks indicators to measure its efficiency. This is the case for almost all other mechanisms, including the much-emphasized participation at International Education Fairs, institutional promotion clips or partnerships.

The perception questions reveal a limited understanding of the concepts of comprehensive internationalization, communication, branding and promotion. While public universities consider that internationalization has a very high or high impact on the quality of education in the university, at the opposite pole there is the private university that perceives internationalization with relative impact (20-40\%) on the quality of education in the institution.

When universities were asked if they consider that the existence of an internationalized curricula has impact on the quality of the program, interestingly enough the private university perceives that an internationalized curriculum has a very high impact on the quality of the program even though the same institution considers 
that internationalization has a relative impact on the quality of education. At the same time, the private university considers that the curriculum of their study programs is internationalized at a very high level, while public universities perceive the curriculum of their study programs internationalized in a relative way. As well, public universities perceive that the existence of internationalized curricula has a high impact on the quality of the program (U1), while the U2 considers the impact in a relative way.

\section{Recommendations for Institutional Level}

For better results, when creating a brand, increasing visibility at international level and attracting international degree students, the following recommendations can be made based on the analysis presented above:

- Universities should pay closer attention to the correlation between objectives and actions; otherwise, they will most likely fail to achieve the stated goals. There is still work when it comes to focusing actions on the stated objectives, and better planning should be put in place in order to use the budget in a more strategic way rather than spending it on actions that are not in accordance with the declared objectives and do not help in achieving anything. For example, in the future, universities could focus more on participating in international fairs that are in the prioritized area countries in order to achieve the desired results or fulfil the strategy objectives.

- For universities to have a realistic perception regarding the correlation between actions and strategy, at the end of each year, I would recommend an exhaustive analysis of all the actions in relations with the stated objectives. This will help them better monitor the process and the results and could make them change or adapt their strategy.

- Universities should develop a marketing strategy, with a mandatory focus on the Why, What and Where, together with an allocated budget.

- In terms of prioritizing countries, institutions should have a realistic approach when defining their target countries that is why I would recommend an in-depth analysis on which countries they should focus and all actions to be in accordance with the chosen objectives.

- Institutions should have clear objectives when presenting their programs, in terms of defining why and what makes the program different and what competencies students will acquire. As well, in order to have a much more focused communication strategy, HEIs should understand what information about the university or the program is relevant for the targeted audience.

- Universities should define Unique Selling Points, which can help prospective students make more accurate choices based on concise points that differentiate universities. Eventually, this can help attract more international students. 
- Universities should consider developing a department or hire specialized human resource representatives in education marketing, to work closely with specialized personnel in recruiting and attracting international students.

- Universities should dedicate more time and resources in creating their own academic brand.

Even though the number of international students increases or may increase, it is important to understand which were the most efficient mechanisms that made international students chose their university, understand where international students seek information, and what type of information they need.

- When monitoring the efficiency of the most frequently used mechanisms, universities should consider new indicators that could help them in the future, focusing their energy or budget better.

- For institutions to be sure that the stated mechanisms ${ }^{3}$ are the most efficient to attract international students, I would recommend a better monitoring of these mechanisms and analyze the data in order to have a certainty whether these are efficient or not.

- To achieve their internationalization strategy objectives, HEIs should pay more attention to developing their educational marketing strategies to enhance mobility further and attract international students.

- The most used social media platforms for the 18-24 group are YouTube, Facebook and Instagram. Therefore, universities should adapt more to these types of platforms, by communicating and promoting their educational offer, as well as branding themselves on these platforms.

- Since 2017, the most populated academic programs with foreign students were taught in French, and in Romania there are only 95 programs in French; therefore, universities should develop more Bachelor programs taught in French.

To sum up, institutions miss several aspects to connect their internationalization strategies with actions. For them to achieve their goals, they should have an action plan that follows each objective.

Even though studies show that prospective students spend a highly ample time on social media, from where they take their information, Romanian institutions seem to ignore this aspect and do not concentrate their efforts in better communicating on social media.

To conclude, it seems universities still do not understand what comprehensive internationalization is, since they perceive the impact of internationalization on the quality of education or the impact of an internationalized curricula in slightly different way.

\footnotetext{
${ }^{3}$ Universities perceive English/the bilingual website, word of mouth (through teachers, students or existing partnerships), participation in International Education Fairs, promotion via other platforms/portals, HEI presentation video in various languages, promotion via studyinRomania.gov.ro portal mechanisms as "highly important", "important" and most efficient mechanisms to attract international degree students.
} 


\section{References}

Bryman, A. (1988). Quantity and Quality in Social Research. New York: 2007th ed. Unwin Hyman Ltd, and simultaneously published by Routledge.

De Wit, H., Hunter F., Howard L., \& Egron-Polak E. (Eds.). (2015). “Internationalization of Higher Education". Brussels: EU: European Parliament.

Deca, L., Egron-Polak, E., \& Fit C.R. (2016). Internationalisation of Higher Education in Romanian National and Institutional Contexts. In Higher Education Reforms in Romania. Between the Bologna Process and National Challenges (p. 138). SPRINGER.

Deca L., \& Fit C.R,. (2015 ). Internationalization of Higher Education Study, Study case Romania. European Parliament.

Egron-Polak, E., \& Hudson, R. (2012). Internationalization of Higher Education: Internationalization of Higher Education: Global Trends Regional Perspectives - the IAU 3rd Global Survey Report. IAU.

EHEA. (2012). Making the Most of Our Potential: Consolidating the European Higher Education Area - Bucharest Communiqué, and Strengthening Mobility For a Better Learning' strategy. Bucharest.

Fernando Angulo-Ruiz, A. P. (2016). The Relevane of Marketing Activities for Higher Education Institutions. In V. Naidoo. Terry Wu, International Marketing of Higher Education.

Institute of International Education. (2019). International student data-leading places of origin. Retrieved from www.iie.org: https://www.iie.org/en/Research-and-Insights/Open-Doors/Data/ International-Students/Places-of-Origin

Jones, E. (2013). The Global Reach of Universities. In R. V. Sugden, Leadership and Cooperation in Academia: Reflecting on the Roles and Responsibilities of University Faculty and Management (pp. 161-183).

Knigh J., \& de Wit H. (2018). Internationalization of Higher Education: Past and Future. International Higher Education, no. 95.

Knight, J. (2008). Higher Education in Turmoil. The Changing World of Internationalization. In Global Perspective on Higher Education. Rotterdam/Taipei: Sense Publishers.

Leask, B. (2009). Using formal and informal curricula to improve interactions between home and international students. Journal of Studies in International Education, 13(2), 205-221.

Marinoni G., de Wit H. (2019). Is Strategic Internationalization a Reality? International Higher Education, no. 98.

Marinoni, G. (2019). Internationalization of Higher Education: An Evolving Landscape, Locally and Globally, IAU 5th Global Survey. IAU.

MENCS. (2016, pp11). Report on the state of higher education in Romania. Bucharest: National Ministry of Education, Research and Sport.

Monitor ICEF. (2017, 07). Mapping the trends that will shape international student mobility. Retrieved from www.icef.com: https://monitor.icef.com/2017/07/mapping-trends-will-shapeinternational-student-mobility/

Pricopie Remus, Reinhardt Zeno, Nicolescu Luminiţa, Almăşan Oana, Bogdan Anamaria, Grecea Daniel (2009). Internationalization of Higher Education, p 9

Redden, E. (2019, 11 18). Retrieved from www.insidehighered.com: https://www.insidehighered. com/admissions/article/2019/11/18/international-enrollments-declined-undergraduategraduate-and

Research Center Pew. (2018). "Social Media Use in 2018”. Center Pew Research.

Savvy, W. (2019, November). Retrieved from www.worldsavvy.org: https://www.worldsavvy.org/ our-approach/global-competence/

UEFISCDI. (2015). Framework for a National Strategy for Internationalization of Higher Education in Romania: Analysis and Recommendations. Bucharest.

UEFISCDI, P. P. (2017). Interntionalization of Higher Education Policy Brief. Bucharest.

UEFISCDI, P. P. (2018). Access in higher education policy brief. Bucharest. 
Open Access This chapter is licensed under the terms of the Creative Commons Attribution 4.0 International License (http://creativecommons.org/licenses/by/4.0/), which permits use, sharing, adaptation, distribution and reproduction in any medium or format, as long as you give appropriate credit to the original author(s) and the source, provide a link to the Creative Commons license and indicate if changes were made.

The images or other third party material in this chapter are included in the chapter's Creative Commons license, unless indicated otherwise in a credit line to the material. If material is not included in the chapter's Creative Commons license and your intended use is not permitted by statutory regulation or exceeds the permitted use, you will need to obtain permission directly from the copyright holder.

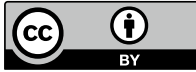

